\title{
Men Want Intelligence, Women Want Love: Sex Differential Use of English Adjectives Among Nigerian University Undergraduate Students
}

\author{
L. Oladipo Salami \\ Department of English, Obafemi Awolowo University, Ile-Ife, Osun State, Nigeria \\ E-mail: lsalami@oauife.edu.ng,diposalami@hotmail.com
}

KEYWORDS Sex; language use; language variation.

\begin{abstract}
This is a sociolinguistic study of the emotional responses of male and female undergraduate students of a Nigerian university using English as an L2. It reports the verbal mapping of these responses in terms of vocabulary choice within some selected topics and attempts to correlate vocabulary usage to speakers' sex. The contexts, which can be appraised to cause emotional responses, include talking about love/joy, morality/guilt and so forth. According to Coon (2001), an emotional stimulus can be external or internal and can make us fearful, sad or happy and it is greatly influenced by how we think about an event (p. 437). The present study demonstrates that men and women tend to appraise the issues investigated differently and their different feelings are reflected in the variable patterns of adjective selection. The study shows that in talking about future partners, while the male students tend to use more of adjectives that focus on their partners' non-romantic qualities such as 'intelligence' and showing 'respect' (focusing on certain determinants of status/hierarchy), the female speakers tend to use adjectives with romantic connotations such as 'loving' and 'caring' (expressing emotional connectedness). In talking about abortion and murder, while the male speakers preferred to use more of religious adjectives like 'evil' and 'satanic', the female students used more of expressively strong moral adjectives like 'dastardly' and 'gruesome'. The study concludes that in Nigeria, there are variations in the use of adjectives by L2 users of English, which among other factors are related to speaker-sex.
\end{abstract}

\section{INTRODUCTION}

It is observed in the literature that in different cultures, people often hold the belief that men and women have different characteristics, including language behaviour. Thus people tend to ascribe one linguistic behavioural pattern to men and the other to women. Tannen (1990:430), observes that even if they grow up in the same neighbourhood, on the same block, or in the same house, girls and boys grow up in different worlds of words. The question of whether or not the male and female sexes speak differently has continued to engage socio-linguists as well as the sociologists of language since Labov (1966) and Trudgill (1972). For example, Cheshire (1982); Russell (1982), Cameron (1985), Coates (1986), Coates and Cameron (1988), Smith (1985), Abu-Haidar (1989), Tannen (1990, 1993), Salami, (1991), Atoye (1995), Imam (1996), Wright (1997); among others, have in one study or the other reported or made mention of language use differences between men and women.

Early studies like Jespersen (1922), Haas (1944, cited in Atoye, 1995) and Fischer (1958) concluded that there are differences in male and female speech. Also, Labov (1966), Wolfram
(1969), Trudgill (1974) and Macaulay (1978) have reported that women tend to approximate closer to the standard norm than men. As noted by Fasold (1990: 92), in these early studies, it has been shown that women tend to avoid socially disfavoured variants in favour of socially more favoured variants. Also Brouwer (1995: 49), observes that women have a more positive attitude towards standard language and men towards non-standard and dialect. Lakoff (1975) claims that the case is that men do speak differently from women and concludes in Language and Woman's Place, that women use more tags and interrupt less in conversation than men. Women are even said to use powerless language (Goddard and Patterson, 2000: 98; citing O'Barr and Atkins, 1980).

\section{TOPIC AND VOCABULARY CHOICE}

Studies of vocabulary choice within topics of conversation have shown that women seem to avoid certain subjects such as money, business and politics while concentrating on people, clothing and decorations. Men, on the other hand, are shown to favour topics such as money, business and sports. This pattern has 
been interpreted as deriving from the fact that traditionally, all over the world, there has been greater engagement of men in paid employment, politics and sports while women are found more in person-oriented domestic situations (Lakoff, 1975). Studies have also claimed that women use more emotive language than men do and that they use the supposedly less assertive, more supportive language and as opposed to the more competitive and dominating behaviour of men (Gramely and Potzald, 1995: 266; citing Glesser et al., and Bate, 1988).

It is important to note, however, that there have been varying explanations for the differences in the choice men and women make of vocabulary items and topics of talk. These range from differences in subject or topic of interest to differences in women and men's socialisation and emotional make-up. One major explanation put forward for the differences in gender-specific vocabulary choice is that there are features which are said to be typical of female use, such as more exact colour terms, for example, 'chartreuse' rather than the male use of 'greenish yellow' or the female 'beige' instead of the male 'light brown' (Lakoff, 1975:8). Furthermore, women are credited with using such intensifiers as 'so'; 'such'; 'quite'; 'vastly'; 'gorgeous' and so on and adjectives such as 'adorable'; 'charming'; 'sweet'; 'lovely' or 'divine' more than men do while men would probably use such words as "helluva" or "damn good" more than women do (Lakoff, ibid. and Key, 1972:19 cited in Gramley and Patzold, ibid: 266).

Also, women are said to disclose more personal information, display emotions more than their male counterparts and that masculine verbal strategy avoids personal admissions, confessions of weakness and failure and display of emotions that reveal vulnerability and dependence (Gramley and Patzold: ibid; ; citing Henley, 1973). In other words, women and men's language behaviour, including vocabulary choice, is likely to be influenced by their emotions. Furthermore, Thorne and Henley (1975) claim that women are more expressive while Gleser et al. (ibid.), for example, claim that women have a stronger tendency to use spatial terms and more oriented towards conveying facts. Studies have also shown that men and women differ in the lengths of their sentences. While studies like Jahr (1992) and Strand (1995) are said to show that men's sentences are said to be more generally longer and contained longer words than women's, Wright (1997) seems to show that women produced longer sentences (Jahr, 1992 Strand, 1995; cited in Wright, 1997).

The studies on sex-differential use of language have sought to explain the perceived differences from three major perspectives. The first is that women have less access to power and status and therefore try to 'make up' for this lack by their preferences for the prestige (standard) linguistic forms. As noted by Fasold (1990: 95), this behaviour of women is said to give them respect and some status. The second perspective is that men and women are socialised in different ways and that this is reflected in their language use patterns (Lakoff, 1975). The third explanatory framework is that in which women and men have different social networks, which lead to women and men using different ways of speaking (see for example, Milroy, 1987; Russel, 1982 and Salami, 1991). Thus, as observed by Wright (1997: 318), whilst we can generalise that men and women do indeed show different linguistic habits, what these habits might consist of vary from community to community.

Cameron (1985), Coates and Cameron (1988) and Tannen (1990 and 1993) have, however, argued that the theoretical and methodological assumptions in early studies of the relationship between language and sex are difficult to generalise. Coates and Cameron (ibid.) argue that the variable sex can be equated with the variable of socio-economic dominance or power. Tannen (ibid.) also asserts that women and men's linguistic practices might vary from one speech community to another and that these practices are influenced by their various subcultures. There is also the argument that much early research treated women as if they were in one category while all sorts of other differences were made to disappear and therefore making research focus very narrow and explanations of variation even narrower. As pointed out by Goddard and Patterson (2000: 98), a question like what kind of woman might use a very elaborate system of colour reference, for example, was never asked in relation to colour vocabulary usage. Also, it is observed in the literature that language usage is affected by context, including the setting, purpose and topic of interaction because it is possible to behave differently, for example, in an academic setting from a pub scene or in discussing politics from computer technology. 


\section{THE PRESENT STUDY}

In this paper, we report the use of English adjectives in three topic contexts by male and female users of English as a second language. Gramely and Patzold (1992: 265) observe that as wide as it is, there have been relatively few studies in the field of vocabulary choice in the sense of sex-preferential usage. They observe, however, that a number of areas have been subject to investigation including, among others, topics of discussion; polite language; taboo words; exclamations; colour terms and spatial concepts. Specifically, they note reports of studies that tend to show that men and women make different choices in their vocabulary usage and expressions such as women's preference for intensifiers, exact colour terms and certain adjectives to men's preference for spatial terms and expressions conveying facts (p. 266).

It is important to note that the bulk of these reported studies have been carried out on English-speaking urban societies of Europe and North America (see Grey, 2002). In the present study, we attempt to explore the language use pattern among male and female undergraduate students of a Nigerian university using English as an L2 to see if there are differences in the choices they make of adjectives. In the study, we attempt to link adjective usage to topic context and proceed from our analysis to suggest that speakers' differing emotions can be reflected in the use of adjectives. As observed by Tannen (1990: 24 - 25), while men tend, in their conversations, to engage the world (acting as a stimulus) in terms of contest, achievement and avoidance of failure, women engage the same world in terms of connections/closeness and achieving consensus. In other words, it is possible that the choices the sexes make of adjectives can be underlined by their differential appraisal of the various emotional stimuli available or present in the world.

Although a number of studies have reported social variation in the use of English as a second language in Nigeria, we are not aware of any systematic study on sex-preferential usage of English adjectives in the country (see Jibril, 1982; Olowu, 1985; Awonusi, 1988 and others). For example, Atoye (1995), in a study of the production and perception of English phonemes among undergraduate students of Obafemi Awolowo University studying English shows that for both female and male students, the female students perform generally better than the male students (p. 85). In other words, Atoye (ibid.) seems to demonstrate that sex is an important variable in English usage in Nigeria. In the present study, we try to investigate the choice of adjectives that are peculiar to each sex in selected talk contexts. These talks focus on issues that we posed to tease the reactions of members of both sexes in order to see if there are differences in their language use.

\section{DATA COLLECTION}

The Setting: The setting of the study is Obafemi Awolowo University, Ile-Ife in the Yorubaspeaking South-western region of Nigeria. The University has a student population of about 20,000 with most of them coming from the Yoruba cultural group. The data for this study were collected through face-to-face interviews that were recorded on audio-tapes. One hundred (100) students were interviewed and they were divided equally into fifty males and fifty females. The one hundred (100) students interviewed were also spread across different disciplines (humanities and the sciences) in the university and different social and religious affiliations. Basic questions about the social life of each student were asked which entailed the students talking at length. We paid attention to the choice of words by each sex group within the topics that were selected for investigation. The mood of the recordings was informal and the interviews held usually in the evenings when the students were back in their halls of residence. The students were told that we were only investigating their reactions to the issues raised for the interview. In other words, it was not clear to them that we were interested in their language usage. It is important to mention, however, that the subjects of this study have all had, at least, thirteen years of English-medium education.

The Language Data As mentioned earlier, the focus of this investigation is the choice of adjectives. According to Aremo (1995), adjectives are open-class items, indefinitely large in number with new members of their class regularly added to them. The Cambridge International Dictionary of English (1996) describes adjectives as words that describe a noun or pronoun. Examples are 'big', 'beautiful', 'adorable', 'intelligent', 'purple', 'gentle', 'little', 'old, 'lovely', 'new', 'bad' and 
so on. In the study we presented the students with three topics in order to tease out specifically their choice of adjectives in the given contexts. As mentioned earlier, our focus was to investigate the peculiar words used by each sex group. The questions asked included the following:

(i) How would you describe your future partner? That is, what qualities would you like to see in a man/woman that would make you want to spend the rest of your life with him/her?

(ii) How would you describe the murder of Bola Ige (Nigeria's Attorney-General)?

(iii) How would you describe the act of abortion?

\section{DATA ANALYSIS AND FINDINGS}

For the purpose of this study, we have devised some heuristics for the classification and description of the English adjectives used by the interviewees in the different contexts selected. The goal is to enable us arrive at some reasonable comparison of the speech practices of the male and female undergraduate students. The audio-tapes were carefully listened to and the adjectives used extracted and subjected to quantitative analysis.

In studies of sex-preferential usage, it is observed that attempts have been made to classify or describe adjectives as those that are 'masculine' - used often by men- and those that are feminine, that is, those that are used mostly by women (see Gramley and Patzold, 1995: 266). In the present study, we have attempted to describe the adjectives used in terms of the idea an adjective expresses or the concept it qualifies. Thus in the responses to the description of a future partner, we have such adjective classifications as

(i) 'romantic-emotive' adjectives, which are the adjectives that express deep emotions/ feelings (examples are words like "caring", "loving", "romantic" etc.);

(ii) 'non-romantic-attitudinal' adjectives which we have further divided into "religious adjectives' ("God-fearing", "spiritual", "godly", 'Christian' etc.) and 'attitudinal adjectives' ("intelligent", "respectful", "trustworthy", "honest") and

(iii) 'physical adjectives' - those that describe physical attributes ("beautiful", "tall", "short", "handsome" etc.).
In the analysis of adjectives used to describe the context of love, we have tried to classify the adjectives in relation to emotion in terms we describe here as 'expressively strong' and 'expressively weak' adjective forms. Here, we are aware also that feelings are usually strong or weak in relation to the question of romance and we have decided to have these two classes of the adjective as some measure of speakers' feelings. Examples of 'expressively weak adjectives' from our data in this context include "nice", "okay", "fine" and "cool" while examples of the 'expressively strong adjectives' used are "splendid", "wonderful", "terrific" and "fantastic"."

In analysing the responses to the topics of morality like murder and abortion, we have classified the adjectives used also into two categories - 'religious' and 'moral.' The reason for having religious and moral adjectives separately is that we are aware that certain words are likely to appear more in religious discourse than in discussing general moral issues. The 'moral adjectives' are further sub-classified into two: 'expressively weak' and 'expressively strong.' Examples of 'religious adjectives' are "satanic", "evil", and "ungodly" while "moral adjectives' elicited include "bad", "callous" and "gruesome". Here, the "expressively strong moral adjectives" include such words as "callous", "gruesome', “inhuman", “dastardly", while "bad", "wrong" and "not okay" constitute 'expressively weak' forms.

It is important to mention here that we do not intend, in this study, the descriptions "weak" and "strong" adjectives to be construed in either positive or negative connotations in terms of the behaviour of the sexes. As mentioned earlier, these are heuristics and their use here has no theoretical implication.

\section{The General Frequency of Adjectives in the Study}

In table 1, we show the frequency of adjective usage by the respondents in the different contexts investigated. The table shows that the total number of times adjectives were used during the interviews was six hundred and twelve (612) with three hundred and nine (309) used by the male speakers while the remaining three hundred and three (303) occurrences were from the female speakers. In other words, adjectives occurred. 
Table 1: Frequency of adjective usage in three contexts by sex

\begin{tabular}{lcccc}
\hline Sex & $\begin{array}{c}\text { Future } \\
\text { partner }\end{array}$ & Murder & Abortion & $\begin{array}{r}\text { Total } \\
\text { adjective } \\
\text { usage }\end{array}$ \\
\hline Male & 190 & 58 & 61 & 309 \\
Female & 198 & 64 & 41 & 303 \\
\hline Total & 388 & 122 & 102 & 612 \\
\hline
\end{tabular}

more frequently in the speech of the men than the women - though in a very small proportion. A breakdown of the data here shows that the male students have higher occurrences of adjectives in the contexts of talking about abortion while the women have more adjectives in describing their future partners and murder. There is no apparent reason here for these dichotomies but when we begin to look at each context of talk as presented in Tables 2 to 5 we should be able to look at the variations more closely.

\section{What Kind of Person do You Desire to Marry?}

As mentioned earlier, in analysing the adjectives used to qualify a future partner, we have four types based on the idea expressed by their use. These classes are 'romantic-emotive', 'non-romantic-attitudinal', 'religious', and 'physical-attribute adjectives'. We observe that while some respondents emphasise the physical attributes of their desired partners by using words such as 'beautiful', 'handsome' and 'pretty', some preferred using words describing feelings that are internal such as 'romantic', 'caring', 'loving' and so on. Table 2 shows the differences in the choice of these four categories of adjectives in the description of a future partner by both the male and female undergraduate students studied.

From the table (2), the total frequency of adjectives used by both male and female students in describing a desired future partner amounts to three hundred and eighty-eight (388), with the adjectives occurring 190 and 198 times in the speech of the male and female students respectively. Out of the 190 occurrences in male speech, 88 or $46.3 \%$ of the occurrences are nonromantic-attitudinal; 47 (24.7\%) physical; 29 or $15.3 \%$ romantic-emotive and $26(13.7 \%)$ religious. The pattern of usage seems to show that the male students used more of non-romanticattitudinal adjectives, followed by physicalattribute, romantic-emotive and religious adjectives in that order, in describing their desired future partners. The female students, on the other hand, used 75 or $37.9 \%$ non-romantic-attitudinal adjectives, followed by 59 (29.7\%) romanticemotive, 41 (20.7\%) physical-attribute and lastly 23 or $11.6 \%$ religious adjectives within the same topic context. The picture we have here is that except in the use of 'romantic-emotive adjectives', the male respondents used more of the adjective types in most of the contexts than the female respondents. The differences between the sexes seem relatively large, however, in the use of the romantic-emotive, non-romantic-attitudinal and physical-attribute adjectives.

\section{What do You Think About Abortion?}

Table 3 shows adjective usage in the context of talking about abortion.

The table 3 shows that the total number of adjectives used within the topic of abortion is (102), with (61) being used by male and (41) by the female students. For the male students, the adjective type that occurs most is the expressively weak moral adjective ( 26 or $42.6 \%$ ) as against women's (21 or $51.2 \%$ ) expressively strong moral adjectives. The men, however, have a higher percentage of occurrence of religious adjectives (11 or 18\%) compared with the women's (4 or $9.8 \%)$. The picture we seem to have here is that for the men, there is not much difference between their use of expressively weak and expressively strong moral adjectives.

\section{How do You React to Bola Ige's Assassination/ Murder?}

Table 4 shows the distribution of adjective usage according to types in the context of talking about murder.

Table 2: Use of adjectives in describing a future partner

\begin{tabular}{lccccc}
\hline Sex & Romantic-emotive & Religious & Non-romantic-attitudinal & Physical-attribute & Total \\
\hline Male & $29(15.3 \%)$ & $26(13.7 \%)$ & $88(46.3 \%)$ & $47(24.7 \%)$ & $190(100 \%)$ \\
Female & $59(29.7 \%)$ & $23(11.6 \%)$ & $75(37.9 \%)$ & $41(20.7 \%)$ & $198(100 \%)$ \\
\hline Total & 88 & 49 & 163 & 88 & 388
\end{tabular}


Table 3: Use of adjectives in talking about abortion

\begin{tabular}{lcccc}
\hline Sex & $\begin{array}{c}\text { Religious } \\
\text { adjectives }\end{array}$ & $\begin{array}{c}\text { Expressively weak } \\
\text { moral adjectives }\end{array}$ & $\begin{array}{c}\text { Expressively strong } \\
\text { moral adjectives }\end{array}$ & Total \\
\hline Male & $11(18 \%)$ & $26(42.6 \%)$ & $24(39.3 \%)$ & $61(100 \%)$ \\
Female & $4(9.8 \%)$ & $16(39 \%)$ & $21(51.2 \%)$ & $41(100 \%)$ \\
\hline Total & 15 & 42 & 45 & 102 \\
\hline
\end{tabular}

Table 4: Use of adjectives when talking about assassination/murder

\begin{tabular}{llccc}
\hline Sex & $\begin{array}{l}\text { Religious } \\
\text { adjectives }\end{array}$ & $\begin{array}{c}\text { Expressively weak } \\
\text { moral adjectives }\end{array}$ & $\begin{array}{c}\text { Expressively strong } \\
\text { moral adjectives }\end{array}$ & Total \\
\hline Male & $5(8.6 \%)$ & $29(50 \%)$ & $24(41.4 \%)$ & $58(100 \%)$ \\
Female & $2(3.1 \%)$ & $20(31.3 \%)$ & $42(65.6 \%)$ & $64(100 \%)$ \\
\hline Total & 7 & 49 & 60 & 122 \\
\hline
\end{tabular}

The total number of occurrence of adjectives in the context of talk about assassination/murder is (122) and (58) of this number occurred in the speech of the males while (64) occurred in the speech of the female speakers. The breakdown shows, however, that 'expressively weak moral adjectives' occurred 29 times $(50 \%)$ in the speech of the male students, followed by 24 or $41.4 \%$ 'expressively strong moral adjectives' and 5 $(8.6 \%)$ 'religious adjectives' in that order. In other words, 'religious adjectives' occurred least in the speech of the male students. The female students, on the other hand, have 42 or $65.6 \%$ of the total number of adjectives used by them here as 'expressively strong moral adjectives', 20 $(31.3 \%)$ 'expressively weak moral adjectives' and 2 or $3.1 \%$ 'religious adjectives' respectively in describing murder. Here also the 'religious adjectives' occurred least in the female speech.

The picture we have then is that although there seems to be no significant difference between the occurrences of 'religious adjectives' in the speech of both sexes, the female students tend to use more 'expressively strong moral adjectives' than the males (42 to 24 ) or $65.6 \%$ to $31.3 \%$ ).

\section{DISCUSSION OF FINDINGS}

\section{Adjectives for a Future Partner}

From the analysis of the data, we note that in talking about future (marriage) partners, both the male and female university undergraduate students in this study used more of what we have described as non-romantic attitudinal adjectives than any other form of adjective. These adjectives include "virtuous", "honest", "intelligent", "trustworthy", "respectful" and "nice" among others. We will observe, however, that the differences between the men and women are relatively more pronounced when we compare their patterns of usage of romantic and nonromantic adjectives. The men seem to use more of non-romantic adjectives than the women $(46.3 \%$ to $37.8 \%)$ while the women use more romantic adjectives than the men $(29.7 \%$ to $15.3 \%)$. In other words, the men seem to emphasise what we have described here as the 'non-romantic-attitudinal' attributes of their future partners (women) while the women placed more emphasis on the 'romantic-emotional' attributes of their future partners (men).

One very interesting aspect of the male nonromantic-attitudinal adjective usage from our data is that the adjective "intelligent" was the most frequent while the women used the adjective "loving" most for their desired future partner. Judging from the number of times this particular adjective occurred - (almost every male interviewed used it), one then starts to wonder whether the men are trying to say that most women are not intelligent or that the intelligent ones are hard to find. One possible interpretation, however, is that they used this particular word more frequently because with university education the men would have acquired a new status and they therefore think it is equitable to have intelligent women as wives (actually, I think what they desire is educated women). The more frequent usage of romantic-emotive adjectives by the female students, on the other hand, might be adduced to the usual claim that women are more emotionally-involved than their male counterpart in matters of the heart. In other words, if it is true that they are more emotionally sensitive than their male counterparts they will 
desire husbands who will be able to meet their high emotional needs. But one can appeal to Tannen's (1990) hierarchy-struggle and connection-consensus hypothesis, by postulating that the choice of the adjective 'intelligent' by the male students tend to demonstrate the status consciousness of men while the use of adjectives like caring and loving by the women also seem to point to Tannen's postulation that women are more concerned with connectedness. Furthermore, the male students' choice of 'non-romantic attitudinal adjectives' in relation to their future partners seems to derive partly from what Kiesling (1998, cited in Coates, 2001: 3) describes as masculinity ideology, which is based on a hierarchy of dominant alignment roles. In the Yoruba cultural context, a female spouse is expected, in relation to her husband, to show, among other things, respect, obedience and virtue. Thus the men in this study have chosen to use such phrases as "respectful women", "obedient women", "virtuous women" rather than "caring women", "loving women" and "compassionate women" in describing their future partners.

Although the differences may be marginal, the men seem to have a higher percentage of adjectives describing physical attributes ('physical adjectives') than the women ( $25 \%$ to $21 \%$ ). It is rather difficult to explain this difference other than to relate it, again, to the men's perception of the world as contest wherein "my wife is prettier than yours" rules. It may be that the men are, underlyingly, motivated by their vision of the world as struggle and contest. Thus it is possible to interpret their 'physical adjective' usage in "mine is better than yours" phenomenon.

\section{Adjectives and Abortion}

The findings of this study show that the female students have a higher percentage of expressively strong moral adjectives than the male students $(51.2 \%$ to $39.3 \%$ ) but used less religious adjectives ( 4 or $9.8 \%$ to 11 or $18 \%$ ) than the men when talking about abortion. Why this is so is not clear other than to say that the women might be doing one of two things. The first is that their behaviour is a manifestation of the mainstream Nigerian non-liberal attitude to abortion. The second is that they might be responding to the question through expressively strong moral adjectives because their lives (women) are involved. For the male undergraduate students, they might be reacting this way because their own lives are not directly involved in this act and therefore may see abortion more from the point of view in which abortion is seen traditionally as a sin while for the women, abortion might not be a religious issue and therefore not a sin. It might be a moral problem where occasionally the lives of women are at risk. It is important to note that in Nigeria, religion is one strong tool of women's subordination because it provides the society (which is maledominated) the argument for controlling women's body.

\section{Adjectives and Assassination / Murder}

From the results of the analysis, we will observe significant differences between the men's use of expressively weak moral adjectives and the women's use of expressively strong moral adjectives. Although there seems to be a thin line between religion and morality, it is difficult to adduce any reason for this dichotomy between the male and female students adjective usage. One point we may want to mention here, however, is that the murder of Bola Ige - the AttorneyGeneral of Nigeria was politically motivated and it is not impossible that the men and women in the present study differed in their appraisals of the incidence. The differing appraisals could have resulted in the variations in adjective usage. Perhaps, it can be argued that the women here are probably more concerned, than the men, with the life of Bola Ige than his politics and therefore manifest this in their use of expressively strong moral adjectives. For the men, it is not impossible that their choice of weak moral adjectives could have been influenced by Nigerian politics. It might be apposite to mention that this seems to agree with Lakoff's (1975) view that one of the areas in which women seem not to be very much involved is politics.

\section{CONCLUSION}

From the findings of this study, it will be observed that speaker-sex and context are important determinants of the selection of English adjectives among Nigerian students using English as a second language. It is important to note, however, that the investigation has held down factors like age of speaker, the impact of speaker-exposure to reading novels and films of western origin and religious-affiliations 
which are not unlikely to have some influence on their choice of adjectives. All these factors influence one's thinking as well as emotional appraisal of subjects and may, invariably, influence one's choice of words and use of expressions. They deserve to be focussed in a further study of language use among Nigerian users of English as a second language.

\section{NOTES}

1. I like to acknowledge the contribution of Ms Biodun Ogunsola of the Department of English, Obafemi Awolowo University to the gathering of the data for this study.

2. I am aware of the use of the term intensifier for the adjectives which I have classified here as 'expressively strong-emotional adjectives'.

\section{REFERENCES}

Abu-Haidar, F. 1989. "Are Iraqi women more prestige conscious than men?: sex differentiation in Baghdadi Arabic". Language in Society, 18: 471-81.

Aremo, B. 1995. An Introduction to English Sentence 1. Ibadan: Caltop Publication (Nigeria) Limited.

Atoye, Raphael O. 1995. "Sex Differentiation in the Acquisition of the Phonology of English as a Second Language". Papers in English and Linguistics (PEL), 1: $75-88$.

Awonusi, V. O. 1988. "Dimensions of social motivation for language change in first and second language English". Ife Studies in English Language, 2(1): 49-60.

Brouwer, D. 1995. "Language and gender: feminist linguistics," (pp. 40-45) in R. Buikema and A. Smelik (eds.), Women's Studies and Culture: A feminist introduction. London: Zed Books Limited.

Cameron D. 1985. Feminism and Linguistic Theory London: Macmillan Press Limited.

Cheshire, J. 1982. "Linguistic variation and social function," (pp. 153-66) in S. Romaine (ed.), Sociolinguistic Variation in Speech Communities. London: Edward Arnold.

Coates, J. 1986. Women, Men and Language. London and New York: Longman.

Coates, J. 2001. "Pushing at the Boundaries: The expression of alternative masculinities," (pp. 2-24) in Janet Cotteril and Anne Ife (eds.), Language Across Boundaries. London: BAAL/Continuum. 2-24.

Coates, J. and D. Cameron (eds.). 1988. Women in their speech communities. Harlow: Longman

Coon, D. 2001. Introduction to Psychology. Belmont, California:Wadsworth/Thomson Learning.

Fasold, R. 1990. Sociolinguistics of Language. Oxford: Basil Blackwell.

Fischer, John, L. 1958/1980 "Social Influences on the Choice of a Linguistic Variant," (pp. 12-17) in A.K. Pugh et. al (eds.), Language and Language Use. London: Heinemann/Open University Press.

Goddard, A. and L. M. Patterson. 2000. Language and Gender. London: Routledge.

Gramley, S. and K-M Patzold. 1992 . A Survey of Modern English. London: Routledge.
Grey, C. 2002. "Towards an over-view of work on gender and language variation".www.edgehill.ac.uk/humarts/ english/rh/modules.html downloaded 22/09/2002.

Imam, Ayesha M. 1996. "Language and Gender" Paper presented at the Nigeria-Sudan Joint Workshop on Gender Sensitisation and Data Analysis, Women and Law Programme, WLUML-RW, Zaria, Nigeria.

Jesperson, O. 1922. Language: Its Nature, Development and Origin. New York: Allen and Unwin.

Jibril, M. 1982. Phonological Variation in Nigerian English. Unpublished Phd. Thesis, University of Lancaster, England.

Labov, W. 1966. The Social Stratification of English in New York City. Washington, D.C.: Centre for Applied Linguistics.

Lakoff, R. 1975. Language and Woman's Place. New York: Harper and Row.

Macaulay, R.K.S. 1978. "Variation and consistency in Glaswegian English", (pp. 132-43) in P. Trudgill (ed.), Sociolinguistic Patterns in British English, London: Arnold.

Milroy, L. 1987. Language and Social Networks. Oxford: Blackwell.

Olowu, C. O. 1985. The Effect of Linguistics Training on the Phonology of Yoruba speakers of English. M.A. Thesis, Obafemi Awolowo University, Ile-Ife, Nigeria.

Olowu, C. O. 1993. "Educational level as a function of competence in the pronunciation of ESL: The example of Yoruba learners of English." Nigeria Journal of Sociolinguistics, 2 (3): 77-95

Procter, P. et al. (eds.). 1993. Cambridge International Dictionary of English. Cambridge: The University of Cambridge Press Syndicate.

Russel, J. 1982. "Networks and sociolinguistic variation in an African urban setting",(pp.125-40) in S. Romaine (ed.). Sociolinguistic Variation in Speech Communities. London: Edward Arnold.

Salami, L. Oladipo. 1991. "Diffusion and Focusing: phonological variation and social networks in IleIfe, Nigeria". Language in Society, 20: 217-45.

Smith, P. M. 1985. Language, the sexes and society. Oxford: Basil Blackwell.

Tannen D. 1990. You Just Don't Understand, Women and Men in Conversation. New York: Ballantine Books.

Tannen D. (ed.) 1993. Gender and conversational interaction. Oxford: Oxford University Press.

Thorne, B. and N. Henley. (eds.) 1975. Language and Sex: Difference and Dominance. Newbury House : Rowley, M.A.

Trudgill, Peter. 1972. "Sex, covert prestige and linguistic change in the urban British English of Norwhich". Language in Society. 1: 179-95.

Trudgill, Peter. 1974. The Social Differentiation of English in Norwhich. Cambridge: Cambridge University Press.

Wardhaugh, R. 1986. An Introduction to Sociolinguistics. Oxford: Basil Blackwell.

Wolfram, W. 1969. A Sociolinguistic Description of Detroit Negro Speech. Washington, D.C.: Centre for Applied Linguistics.

Wright, L. 1997. "Sex differences in historical syntax: Early Modern English testimonies in the MS Minutes of the Court of Governors of the Royal Hospitals of Bridewell and Bethlem 1559. Studia Anglica Posnaniensia: An International Review of English Studies, XXXI: 317 - 344 